\title{
WEIGHTED OSTROWSKI TYPE INEQUALITIES BY LIDSTONE POLYNOMIALS
}

\section{Andrea Aglić Aluinović, LJILJAnKa KVesić And Josip PEČARić}

Abstract. We present a weighted generalization of Ostrowski type inequality for differentiable functions of class $C^{n}$ presented by Lidstone interpolating polynomial.

Mathematics subject classification (2010): 26D15, 26D20.

Keywords and phrases: Ostrowski type inequality, Lidstone polynomials.

\section{REFERENCES}

[1] R. P. Agarwal, P. J. Y. Wong, Error Inequalities in Polynomial Interpolation and Their Applications, Kluwer Academic Publishers, Dordrecht/Boston/London, 1993.

[2] A. Aglić Aluinović, A. ČIVljak, S. Kovač, J. PeČARIĆ, M. Ribičić Penava, General Integral Identities and Related inequalities, Element, Zagreb, 2013.

[3] G. Aras-Gazić, V. ČulJak, J. PeČArić, A. Vukelić, Generalization of Jensen's inequality by Lidstone's polynomial and related results, Math. Inequal. Appl. 16 (2013), 1243-1267.

[4] G. J. Lidstone, Notes on the extensions of Aitken's teorem (for polynomial interpolation) to the Everett types, Proc. Edinburgh Math. Soc. 2, 2 (1929), 16-19.

[5] D. S. Mitrinović, J. E. PeČArić, AND A. M. FinK, Inequalities for functions and their Integrals and Derivatives, Kluwer Academic Publishers, Dordrecht, 1994.

[6] A. OstrowsKI, Über die Absolutabweichung einer differentiebaren Funktion von ihrem Integralmittelwert, Comment. Math. Helv. 10 (1938), 226-227.

[7] J. PeČARIĆ, On the Čebyšev inequality, Bul. Inst. Politehn. Timisoara 25 (39) (1980), 10-11.

[8] D. V. WidDER, Completly convex function and Lidstone series, Trans. Am. Math. Soc. 51 (1942), 387-398. 